24. デンタルフィルム PHIL-X30" について

小川 和久・森 進一郎・原田 吉通

(福歯大・䱊放)

歯科䛦療における日内法 X線撮影においては，prepack された專用のデンタルフィルムが用いられるが， この撮影済みフィルムの処理においては，歯科診療のも つ特殊性のゆえに，暗室を用いないインスタント方式で の処理が行われる場合が多々ある.

このインスタント方式の処理法としては，我が国では 注射筒を用いて処理液をフィルムパッケーシシ内に注入し て処理を行う方式が一般的であるが，今回，我々は諸外 国で使われている，フィルムパッケージの中に処理液ま で包装されている "self-developing type" のデンタル フィルム PHIL-X30”を入手し，乙れをテストする機 会を得た。

そこでこの "self-developing dental film" の基本 的な特性を求め，また現在我が国で広く用いられている 阪神技研の “instant film”との比較検討を行なった結 果，次のことがわかった。

1) PHIL-X30" は, 感度, コントラスト, カブリの 面からみて，阪神インスタントフィルムとほぼ同様の結 果を示した。また MTF の面からもほとんど差はなか った。

2) PHIL $-X 30 "$ は，現像処理そのもは，処理液の乙 ともあまり気にせずに容易に行うことができるが，撮影 に際して大きなフィルムパッケージが邪魔になるてとが ある。

\section{5. 重症心身㢓害児（者）の言語状態}

柿木 保明・熦崎 文彦

(九歯大・口科)

今回, 重症心身障害児（者）の口腔機能と言語機能状 態との関連性を把握する目的で, 国立南福岡病院重症心 身障害児病棟に入院中の患児 (者)，95名（2-26歳， 平均年齢16歳 6 力月) について言語状態および捸食状態 について調査を行った。

コえュニケーションとしての言語状態については，言 語に対する理解度, 表現手段, 表現内容および発語明瞭 度の障害度别に分類し，それらを合わせて言語障害度と した. また摄食状驡は, 上肢の機能や上半身の姿勢保持 能力および咀嚼・噗下困難の有無等により分類し，言語 障害度との関連性について検討を行い，次の結果を得
た。

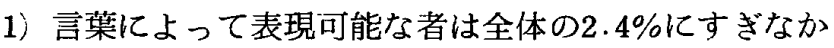
った。

2）理解不能および発語のない者は全体の $88.4 \%$ に及 んだ.

3）摂食時に介助を必要とする者は，自食できる者に比 べて有意に $(\mathrm{p}<0.001)$ 言語障害度が高かった。

4）咀嚼・睘下困難のある者は困難のない者に比べて有 意に $(\mathrm{p}<0.05)$ 言語障害度が高かった。

以上より，擷一舌一口唇一軟口蓋の随意的協調運動で ある摂食行動と言語状態との間に相関性があるととが認 められた。

\section{6. 各種動物肝䑏の Alanine: glyoxylate amino-} transferase 1 (AGT 1) の進化

高田 義一・野口 知雄

(九歯大·生化)

Alanine: glyoxylate aminotransferase (AGT) は 多くの動物種の肝藏に広く分布する $\mathrm{B}_{6}$ 酵素である。本 䣼素は L-alanine と glyoxylate とのアミノ基転移反 応を非可逆的に触媒する。哺乳動物の肝藏には, 性質 の異なる二種の AGT isozyme (AGT 1, AGT 2) が ある. このうち AGT 1 は分子量 80000 で 2 個の同一 subunit からなり，以下の特徴をもつ．(1) AGT 1 の細 胞内分布は動物種により著しく異なる，すなわち，霊長 類やウサギ，モルモットでは peroxisomes に，イヌ， ネコではmitochondria に，又ラット，マウスでは両者 に局在する．（2）AGT 1 の基質特異性は種により著し く異なる。すなわち，ラット，マウスの AGT 1 が， glyoxylateを用いて,多くの L-amino acid 亿作用する のに対し，ヒト，サル，イヌ，ネコなどの AGT 1 は L-alanine と serine にしか作用しない。(3)細胞内局在 や基質特異性が著しく異なるにもかかわらず，各種動物 の AGT 1 は，免度学的交叉を示すととから，てれらの 酵素は共通の祖先に由来するてとが示唆される(1)．今 回, 抗ラット AGT 1 を用いて各種動物 AGT 1 間のア ミノ酸配列の類似性を免度学的距離から推定した。その 結果, (1)同一種の peroxisomes と mitochndria の AGT 1 はおそらく同じアミノ酸配列をもつ. (2)異なる 動物種の mitochondria あるいは peroxisomes の AGT 1 は orthologous な蛋白である. (3) AGT 1 の単 位進化所要年数は約 $2.2 \mathrm{Myr}\left(=10^{6}\right.$ 年) である. 以上 は，動物種により練胞内分布や基質特買性の異なる 